\title{
Analysis of Securities Analysts Impact on China's Capital Market Efficiency
}

\author{
Bing Yang ${ }^{1} \&$ Xiaolin $\mathrm{Li}^{1}$ \\ ${ }^{1}$ School of Economics, Jinan University, Guangzhou, China \\ Correspondence: Xiaolin Li, School of Economics, Jinan University, No.601, West Huangpu Avenue, Tianhe \\ District, Guangzhou, Guangdong, China. Tel: 86-20-8522-2843.
}

Received: February 27, 2017

Accepted: March 14, 2017

Online Published: March 20, 2017

doi:10.20849/ajsss.v2i1.127

URL: https://doi.org/10.20849/ajsss.v2i1.127

\begin{abstract}
This paper explores the impact of securities analysts on China's capital market efficiency from the perspective of the stock price synchronicity. Empirical results show that increased securities analysts can improve capital market efficiency, but this effect is limited with economical insignificant. We recommend that the Chinese Securities' Regulatory Authorities need to further the reform of the securities industry consulting system, thus enhance the capital market efficiency of allocation of resources.
\end{abstract}

Keywords: securities analyst, stock price synchronicity, market efficiency

\section{Introduction}

As an important participant in the capital market, the securities analyst plays an important role of information processors and communicators, and their work of guiding investors to rational investment, promoting capital market efficiency has important significance. In China, the securities analyst industry has made rapid development in the past decade, but the comments for the evaluation of securities analysts are different.

Zhu Hongjun, He Xianjie and Tao Lin (2007) use the data from 2004 to 2005 for empirical testing, it holds that although there are many questions about the role of securities analysts for the market, but ian is undoubtedly that securities analysts in China play a positive role in promoting the capital market efficiency. Their information-based search and information processing activities enable enterprise-level information to be more included in the company's stock price, reduce the phenomenon of drift after the earnings announcement, and make the current share price to more timely reflect the future earnings information. And as a result, reducing the stock price synchronization, and promoting the efficiency of market operation.

Cai Qingfeng \& Yang Kan (2013) use the data of listed companies Shanghai and Shenzhen Stock Exchange from 2005 to 2011 as a sample to explore the decision made by the securities analysts. It holds that securities analyst's decision-making adjustment mostly based on the company's intangible information, rather than the company's fundamentals information. And when securities analysts making the earnings forecast, they would also have a comprehensive study of the company's fundamentals in the consideration of accuracy. However, further empirical analysis found that the pursuit of intangible information of securities analysts is not conducive to the improvement of market efficiency. The more analysts concerned about the intangible information of the enterprise, the lower the unique information included in the company's share price, and the higher the synchronization with the stock market.

This paper attempts to further explore whether the participation of securities analysts in recent years has promoted the improvement of capital market efficiency in our country on the basis of the above literature.

\section{China Securities Analyst Industry Development History Review}

\subsection{The Definition and Classification of Securities Analysts}

A securities analyst is a professional in the securities market who is employed by a securities firm, a bank or an investment company, using an analytical method of economics, management, and finance, issuing research reports on the basis of a comprehensive investigation and analysis of a related industry or a listed company, and giving specific recommendations related to investment.

According to the securities analyst to provide differentiated clients, analysts in the securities market can be 
divided into three categories: the seller's analyst, the buyer's analyst, and the independent analyst.

The securities analysts described in this article refer specifically to the seller's analyst, working in the research department of the securities company (investment bank), whose research is mainly sold to institutional investors and can also be obtained by individual investors. These studies will generally be published, and the media and investors will often quote them.

\subsection{The Functions of Securities Analysts}

The basic functions of a securities analyst include:

1) Information Collecting. Securities analysts are employed in securities companies and most of them have a specific professional background. With the support of securities companies, they can collect information on industries or listed companies continuously. They generally continue to track the listed companies by reading public information, participating in corporate announcements, visiting listed companies and so on. Ordinary investors are subject to professional background or information costs may not be able to complete such work.

2) Analysis and Evaluation. After the collection of various information, securities analysts will use their own expertise to conduct a comprehensive analysis and treatment, and express the study in the popular language as far as possible that their readers can be more easier to grasp the future development trend of listed companies thus inform their own investment decision.

3) Making investment advice. This is the final goal of the analysis of securities analysts. Securities analysts have to give their investment advice to investors based on their own analytical logic, but sometimes this is not necessary. General investment advice, including buy, hold, neutral and sell.

Thus the basic function of the securities analyst is to analyze and evaluate the individual securities such as stocks and bonds on the basis of the industrial survey and the enterprise survey, and then provide the investment information by providing the investor with the investigation report. Therefore, theoretically, securities analysts guide investors to make the decision through the search for information and the ability to handle information Therefore, it could lead to a result of reducing information asymmetry, improving the efficiency of information flow, making the operation of the securities market more effective, and thus contributing to increasing the capital market efficiency. The following will be a further empirical analysis of whether this effect is achieved.

\subsection{The Development of Securities Analyst Industry of China}

The securities analyst industry in China is accompanied by the development of China's securities market development and growth, and its development process can be roughly divided into the following three stages.

The first stage is the initial stage (1991-1998). The main features of this stage for the securities analysts is that they are not included in the regulatory system, practitioners are mixed, with very little fundamental analysis and lack of professional skills. Thus as a consequence, there were quite a lot of disputes.

In the early 1990s, when the securities market was established, in order to meet the needs of the securities companies, the securities consulting departments have set up. At first, the customer service department was set up by the securities company, but it is just provide the "novice guide" to the investors, and is far from the strict sense of the consulting business. At this stage, the stock market has just been established, investors are still relatively unfamiliar with stock market. At this time, the role of securities analysts is more likely to be an entry guider of stock market. Then, China's securities market has been through a rapid development process. Due to the speculative atmosphere of the securities market, investors' investment decisions are basically based on the "policy", "dealer", "insider" and other concepts. In order to meet the needs of investors' speculation, various kinds of "stock analysts", "market participants", "securities researcher" were actively appearing in the stock exchange and various news media. The news media also fueled and the market regulation is still a blank. In this environment, the securities analyst industry has a large number of violations.

The second stage is the normative stage of development (1998-2002). With the issue of "Securities and Futures Investment Advisory Interim Measures" and "Securities Law", the securities analyst industry was incorporated into the regulatory system, but practitioners are still lack of professional skills. The fundamentals analysis is rough and stock-comment analysis is still in the main position.

In this stage, the securities analyst industry enters into the stage of standardized development, all kinds of management regulations have been incorporated, the government began to monitor this industry. Under the situation of the self-indulgence and large-scale irregularities in the securities consulting industry, the regulators began to pay attention to of securities analyst industry. In April 1st, 1998 the "Interim Measures on the Administration of Securities and Futures Investment Advisory and the Implementation Rules of the Securities 
and Futures Commission" promulgated and implemented, and the government began to start qualification examination of the institutions and practitioners. On July $16^{\text {th }}$ of 2000 , China promulgated the "Code of Professional Ethics for Chinese Analysts", and on December 13rd of 2002, the Securities Regulatory Commission of the Securities Industry Association was set up to make the management of securities analysts standardized. However, the vacancies of supervision for many years, as a result, the overall quality of the securities analysts industry is low and short-term speculative mentality has been deeply rooted, many securities analysts lack patience on long-term and in-depth study. Besides, the investors have not formed a wide need of range of securities analyst research report.

The third stage is the phase of seller's analyst (from 2002 to now). With the internationalization of China's securities market and the rapid growth and the development of institutional investors, the seller's analysts with the concept of basic analysis and value investment relying on the institute of brokers has gradually become the mainstream of the securities consulting industry. The new stage of this industry forms a wide range of impact to multiple levels of investors on the securities market.

On November $10^{\text {th }}$ of 2001, China joined the World Trade Organization (WTO). With the accompanying, China's securities market gradually open to the international market, especially the implementation of QFJI system has a significant impact on the securities analysis industry. At the same time, driven by the policy of vigorously developing institutional investors, institutional investors, represented by securities investment funds, are going through a rapid development. These landmark events have a far-reaching impact on the change of investment philosophy of China's securities market. The speculative concept of "insider information", "go with the dealer", and "technical analysis" are gradually declined, in contrast, the study of the company's fundamental analysis of the value of the investment is becoming more popular.

Since then, investors are focusing on the basic situation of the enterprise instead of the flow of capital. The stock returns to securities based on the value of the enterprise from the "game chips". These profound and irreversible changes have significantly affected the industrial chain structure of securities investment. The complexity and differences of macroeconomic, industrial and listed companies requires the professional researchers to conduct further study and continuous tracking, which directly and inevitably led to the "professional division of labor", namely: professional division of labor on investment and research, and on different research areas. The professional division of labor on investment and research reflects the need of professional research of securities companies by investors. The professional division of labor different research areas leads to the growth of research team of securities companies. As a result, the seller's analyst which is mainly relying on the securities companies and specifically giving reports to external institutional investors to provide information services has become the mainstream of the securities investment advisory industry.

According to WIND database statistics, at the end of 2014, the number of researchers of China's securities research institute is 1443 , covering 9.25 companies per researcher.

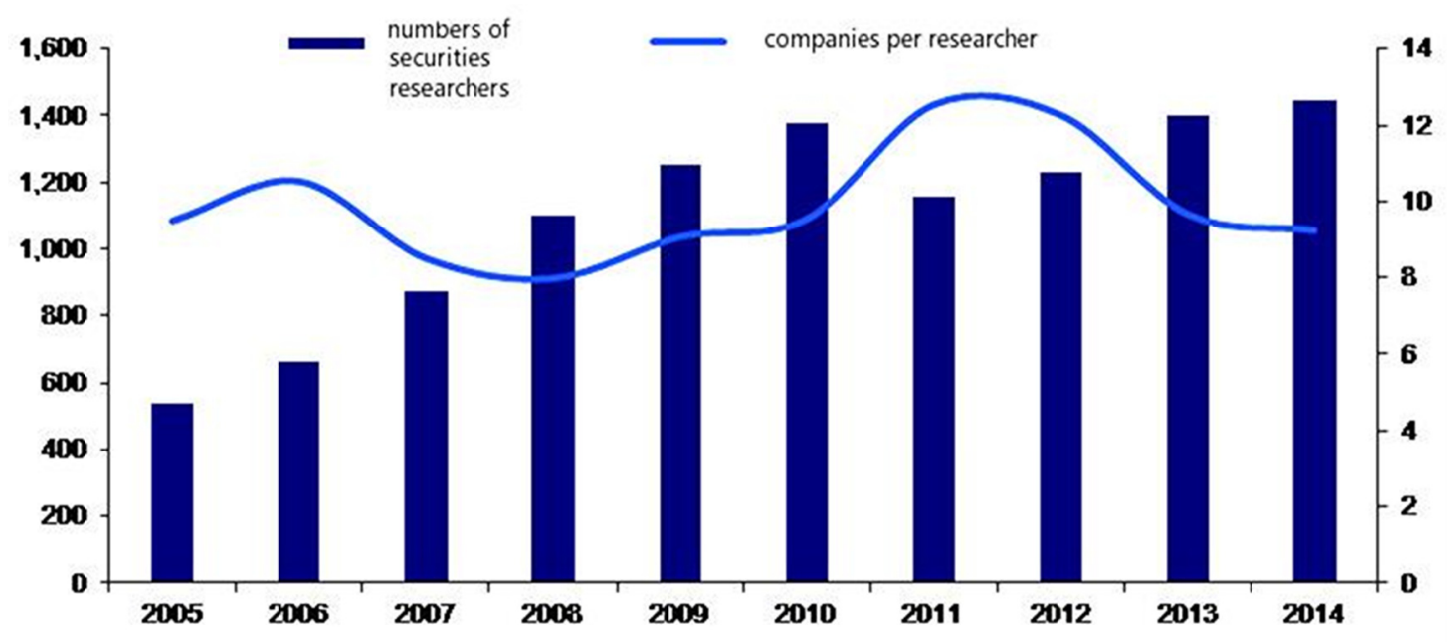

Figure 1. Numbers of securities researchers of China and companies per researcher

Source: Wind database 


\section{The Empirical Model}

\subsection{Sample Selection and Data Sources}

In the sample, the selected company samples are the A shares (excluding financial enterprises) which was continued tracked by securities analysts during 2005 - 2013. There are 841 companies in total.

This paper chooses the consolidated A-share index, the stock and the market index return rate, which are the weekly returns, and are the return rates of the cash dividend reinvestment, which is derived from the data from the CSMAR database. The remaining variables of the original data are derived from the WIND database.

\subsection{The Measurement of Share Price Synchronization}

We define the weekly return rate of a stock as $R_{i}$, the weekly market rate of return as $R_{m}$ (the market rate of return data using the integrated A-share index provided in the CSMAR database) and the contingency coefficient as $R^{2}$. Using the CAPM model to regress $R_{i}$ and $R_{m}$. And the contingency coefficient $R^{2}$ of the regression equation is used as an indicator of stock synchronization.

$$
R_{i}=\alpha+\beta \times R_{m}+e
$$

The economic meaning of the $R^{2}$ is the part of the change in the stock price of an individual company that can be explained by market volatility. Therefore, the larger of $R^{2}$, that the company's stock price contains more market-level information, less company-level information, and it means that its synchronization is greater. Since the value range of $R^{2}$ is $(0,1)$, and it does not meet the regression requirements of the least squares method, so we put $R^{2}$ into the following logarithmic conversion:

$$
S Y N=\operatorname{LOG}\left(\frac{R^{2}}{1-R^{2}}\right)
$$

\subsection{Regression Model Design}

According to the analysis of Zhu Hongjun, He Xianjie and Tao Lin (2007), we use the following regression model to analyze the impact of the number of securities analysts on stock price synchronization:

$$
S Y N=a+b_{1} \times \text { analyst }+b_{2} \times \ln \text { asset }+b_{3} \times \text { turnover }+b_{4} \times \text { roe }+b_{5} \times l e v+\mu
$$

For the control variables, we use the natural logarithmic form of the company's annual average assets and define it as Lnasset. And define the company's annual average turnover rate as Turnover, the company's annual average return on equity as ROE, the company's annual average asset-liability ratio as Lev. We use these control variables to control its impact on stock price synchronization, using the annual data from 2005 to 1013 to do the model regression.

If the participation of the securities analysts can reduce the stock price synchronization, increase the amount of the company level information contained in stock price, then the forecast coefficient $b_{1}$ would be negative. On the contrary if the securities analyst's participation is "hearsay", that is the participation of the securities analysts can not reduce the stock price synchronization, and can not increase the amount of the company level information contained in stock price, then the forecast coefficient $b_{1}$ would be positive.

\section{Empirical Test}

\subsection{Descriptive Statistics}

Table 1 shows the descriptive statistics of the relevant variables of the sample companies. It can be seen from Table 1 that the mean and standard deviation of the synonymity (Syn) are (-0.660) and 0.969 respectively. And the share price synchronization is corresponding to the mount of the company level information of the stock price. According to the indicators of the stock price synchronization and stock price information in literatures, we can conclude that they are opposite. Therefore, the average amount of the information of stock of the selected sample company is 0.66 and the standard deviation is 0.969 , which indicates that there is a big difference in the stock price information between companies. The average and standard deviation of analysts' analysts are 18.841 
and 14.780 respectively, indicating that there are significant differences between the number of securities analysts who track and analyze different companies.

Table 1. Variable definitions and descriptive statistics (2005 - 2013)

\begin{tabular}{|c|c|c|c|c|c|c|}
\hline Variable & Definition & $\begin{array}{l}\text { Sample } \\
\text { size }\end{array}$ & Mean & $\begin{array}{l}\text { Standard } \\
\text { Deviation }\end{array}$ & Minimum & Maximum \\
\hline Syn & Synchronous price & 7173 & -0.660 & 0.969 & -10.748 & 1.982 \\
\hline Analyst & $\begin{array}{c}\text { Number of Securities } \\
\text { Analysts }\end{array}$ & 7173 & 18.841 & 14.780 & 1 & 71 \\
\hline Lnasset & Annual average assets & 7173 & $1.03 \mathrm{E}+10$ & $3.94 \mathrm{E}+10$ & $4.05 \mathrm{E}+07$ & $1.32 \mathrm{E}+12$ \\
\hline Turnover & $\begin{array}{l}\text { Annual average } \\
\text { turnover }\end{array}$ & 7173 & 2.381 & 1.610 & 0.040 & 13.323 \\
\hline ROE & $\begin{array}{c}\text { Annual average return } \\
\text { on equity }\end{array}$ & 7173 & 7.970 & 16.147 & -489.130 & 159.965 \\
\hline Lev & Annual average asset & 7173 & 51.026 & 18.617 & 0.173 & 109.421 \\
\hline
\end{tabular}

\subsection{Regression Results}

Table 2 reports the results of regression based on panel data. According to the Hausman test results, we choose the fixed effect model. And in the fixed effect model, we report the regression results of the one-way fixed effect model and the bidirectional fixed effect model respectively. It can be seen that there is a negative correlation between the number of securities analysts who track the company and the synchronization of its stock price of the company whether it is a one-way or a two-way fixed effect model. This negative correlation is only significant at the level of significance of $10 \%$. The results can be shown that with the increase of the number of securities analysts to this company, the amount of the information of its stock price increased that means the company's share price and synchronization of the market index reduced.

In addition, the regression coefficient of Lnasset (the natural logarithmic form of asset) of the firm is significantly positive at the $1 \%$ level, and the absolute value of its coefficient $(0.185)$ is larger than that of other variables, which is economically significant. This shows that the larger the company, the higher the stock price synchronization. One of the possible reasons is that the larger the company, the company's stock price in has higher share of market index, and that would lead to the higher the stock price synchronization. At the same time, the time variable of the two-way fixed effect model is significant at the statistical level, and the fitting degree $R^{2}$ of the model is improved greatly with respect to the one-way fixed effect model. However, the coefficient of the time variable is different with the year, there is no obvious law, and there are some coefficient is not significant in the statistical level of some years.

Table 2. Regression analysis results

\begin{tabular}{ccc}
\hline Variable & One-way FEM & Two-way FEM \\
\hline analyst & $-0.004^{*}$ & $-0.004^{*}$ \\
& $(-1.85)$ & $(-1.69)$ \\
lnasset & $0.185^{* * *}$ & $0.258^{* * *}$ \\
& $(5.07)$ & $(7.78)$ \\
turnover & $-0.103 * * *$ & $-0.080^{* * *}$
\end{tabular}




$\begin{array}{cc} & -0.005 * * * \\ & (-6.79) \\ \text { lev } & -0.009 * * * \\ & (-6.71)\end{array}$

year2006

year2007

year 2008

year2009

year 2010

year2011

year2012

year 2013

Constant term
$-0.004^{* * *}$

$(-6.17)$

$-0.008^{* * *}$

$(-7.19)$

$-0.677 * * *$

(-16.30)

$-0.377^{* * * *}$

$(-7.80)$

$0.666^{* * * *}$

$0.206^{* * *}$

$-0.270 * * *$

0.02

(0.38)

0.03

(0.55)

$-0.772 * * *$

$(-13.66)$

$-5.508 * * *$

$(-8.01)$

7173

0.282

0.191

192.536

Thus, according to the results of the regression in Table 2, we can conclude that, on the whole, China's securities analysts' information search activities can reduce the synchronization of stock prices and increase the amount of information about the company's fundamentals in its stock price. This is consistent with the analysis of Zhu Hongjun (2007), but only at a level of $10 \%$, and can not provide strong evidence to prove the above conclusions, and thus can not provide strong proof to against the study of Cai Qingfeng (2013). Cai Qingfeng et al (2013) believe that securities analysts in the information collection and processing preferences "hearsay", chasing hot spots of industry, stories and even gossip and other intangible messages, which will reduce the company's share price information content.

\section{Conclusion and Revelation}

Through the above analysis, this paper argues that although the securities market in our country has made great progress in recent years, that is, the empirical results show that the number of securities analysts is negative at the significance level of $10 \%$, but the professional reputation of securities analysts is still not optimistic, that is, the significant level is not high.

Theoretically, the function of securities analysts is to dig the information of company's characteristics in order to serve all kinds of investors, which means, with the increase of the numbers of securities analysts of a company, the company's share price information content will improve, that is, the synchronization of the company's share price will be reduced, so as to promote the efficiency of capital market.

This paper suggests that China Securities Regulatory Commission need to further deepen the reform of the securities consulting industry, with reference to the securities consulting industry system of the world's advanced countries and explore the securities consulting industry system in line with China's national conditions, promote the healthy development of China's securities market and enhance the signal of China's securities market 
Mechanism to improve the efficiency of capital market allocation of resources.

\section{References}

Asquith, P., Mikhail, M. B., \& Au, A .S. (2005). Information content of equity analyst reports. Journal of Financial Economics, 75(2), 245-282. https://doi.org/10.1016/j.jfineco.2004.01.002

Cai, Qingfeng, \& Yang, Kan. (2013). Who is in the "hearsay": institutional investors vs securities analyst - based on A-share information traders information preferences empirical research. Finance Research, (6), 193-206

Chan, K., \& Hameed, A. (2006). Stock price synchronicity and analyst coverage in emerging markets. Journal of Financial Economics, 80(1), 115-147. https://doi.org/10.1016/j.jfineco.2005.03.010

Daniel, K., \& Titman, S. (2006). Market reactions to tangible and intangible information. The Journal of Finance, 61(4), 1605-1643. https://doi.org/10.1111/j.1540-6261.2006.00884.x

Zhu, Hongjun, He, Xianjie, \& Tao, Lin. (2007). China's securities analysts can improve the efficiency of capital markets - based on stock price synchronization and stock price information empirical evidence. Finance Research, (02A), 110-121.

\section{Copyrights}

Copyright for this article is retained by the author(s), with first publication rights granted to the journal.

This is an open-access article distributed under the terms and conditions of the Creative Commons Attribution license (http://creativecommons.org/licenses/by/4.0/). 